doi 10.17072/1994-9960-2016-4-66-73

UDC 336:338.45(470+571)+55)

LBK 65.26+65.30(2Рос+5Ирн)

\title{
THE IMPACT OF FINANCIAL MARKET ON INDUSTRY GROWTH: AN EVIDENCE FROM RUSSIA AND IRAN
}

\author{
I.G. Sergeeva, Doctor of Economic Sciences, Professor, Head of the Department \\ of Financial Management and Audit \\ E-mail: Igsergeeva@gmail.com \\ Saint-Petersburg National Research University of Information Technologies, Mechanics and Optics, \\ 9, Lomonosova st., Saint-Petersburg, 191002, Russian Federation
}

T. Tayebehsadat, Postgraduate student

E-mail: Tstaba64@gmail.com

Saint-Petersburg National Research University of Information Technologies, Mechanics and Optics, 9, Lomonosova st., Saint-Petersburg, 191002, Russian Federation

The relationship between financial markets and industry growth has been approved by many previous studies. In this paper, as an innovative research, we try to find the impact of market capitalization in financial market as a proxy for financial market on the industry growth in Russia and Iran. In fact, these two countries are classified as developing economies in which the financial markets can play a powerful engine to improve the industries' performances. Hence, it would be interesting to compare market capitalization-industry growth nexus in Russia and Iran as two developing countries. In order to fulfill this purpose, an econometric model called Vector Autoregressive Model (VAR) is applied for the annual data over the period of 1992-2014. The finding proves the positive relationship between market capitalization and industry growth in both countries, Iran and Russia. Based on the results, a $1 \%$ increase in market capitalization in Iran and Russia increases the industry growth by $0.07 \%$ and $0.02 \%$, respectively. It has been concluded that market capitalization can play a significant role in order to grow the industry in Iran and Russia. However, these two countries need to improve the efficiency of their financial markets to improve the positive impact of these markets on their industrial growth. The novelty of this research can be highlighted in this way that the financial market in oil exporting countries, Russia and Iran as our case studies, may be a golden key to reach to a positive and stable economic growth. Thereby, oil exporting countries should try to implement good financial policies and improve the efficiency of financial market.

Keywords: market capitalization, Iran, Russia, industry growth, time series analysis, economic modeling, Vector Auto Regressive Model, unit root test, lag selection, co-integration test.

\section{Introduction}

It is always discussed that industrial growth in an economy hinges on efficient financial markets, which pool domestic savings and mobilized foreign capital for productive investment in an industry. It is clear that without effective financial institutions, productive and necessary industrial projects may remain unexploited. In fact, inefficient financial institutions (or in other words markets) will have the influence of taxing productive investment and thus decreasing scope for improving the stock of equipment required to compare globally. It is a real fact that inefficiency in the financial markets can substantially cut growth from the industry in an economy.
Another crucial point is that inappropriate or underdeveloped functioning financial markets deter foreign investors due to this fact that the markets are illiquid and doing trade is expensive. Direct investment in an industry is negatively influenced if raising domestic capital in the financial markets is difficult and expensive.

\section{Literature review}

The attention to the role of financial markets in an economy goes back to Bagehot and et al. [1] and J. Schumpeter [18] who explained the importance of the financial market effects on economic and industrial growth. Over the years, many economists have tried to develop this relationship through some theoretical models. For example, R. Levine [9] and Bencivenga et al. [3] 
introduced a model in which more liquid markets may lead to long-term investment increase and industrial growth. A. Shleifer and R.W. Vishney [17] and A. Bhide [4] discussed that good financial markets may lead to liquidity increase, which would have an impact on resource allocation and slowing industrial growth in a country. Furthermore, a group of studies has focused empirically on this matter. R. Levine and S. Zervos [10] proved that stock market liquidity positively affects industrial growth. R.G. Rajan and L. Zingales [15] found that stock market size has a long run relationship with industrial development. T. Beck and R. Levine [2] investigated the relationship between industry growth and capital allocation. Their findings depict that bank-based financial system is better at financing the expansion of industries. Kim et al. [8] showed that industries dominated by small firms grow faster in a country with a more bankbased financial systems. They also found that the impacts of financial structure on industry growth runs chiefly in a way that growth in the amount of establishments rather than through growth in the average size of establishments.

In this study, we will provide a case study based investigation of the relationship between financial markets and industry growth in two countries, i.e. Iran and Russia. Since these two countries are classified in the developing economies, this investigation would be interesting and give some useful policy implications.

The study is structured as follows: The next section presents a brief literature review. After that methodology is discussed. The results are considered in the next and the last section concludes the paper.

In this paper, we consider market capitalization as a proxy for financial market and try to explore its effect on industry growth in Iran and Russia. Theoretically, industry growth in a country depends on various factors such as production cost, demand, competitors, etc. One of the most important factors is the stock market. In fact, as Dicle et al. [5] mentioned, a well developed stock market can improve industry growth in a country by encouraging people to increase investment in industry sectors. In other words, the stock market can transfer liquidity from households to entrepreneurs or industries. The market capitalization is an indicator which shows the growth or fall of the stock market. Growth in the market capitalization means a more developed financial sector, better bond and equity market, as well. This circumstance would lead to industry growth in a country. R. Levine and S. Zervos [10] discuss that market capitalization (market value) is a crucial issue in regards to improving productivity by enhancing the efficiency of financial intermediaries, increasing the MPC (marginal productivity of capital) as well as making growth in the saving rate.

\section{Trends of market capitalization and value added in industry}

In the last decades, Russia and Iran have experienced growth in their market capitalization, except in some unusual periods such as the Russian financial crisis in 1998 and 2009, financial sanctions against Iran after 2010 or sanctions against Russia after 2014 . The market capitalization of listed companies in these two countries over the period 1992-2014 which are collected from the World Bank is shown in the following fig. 1.

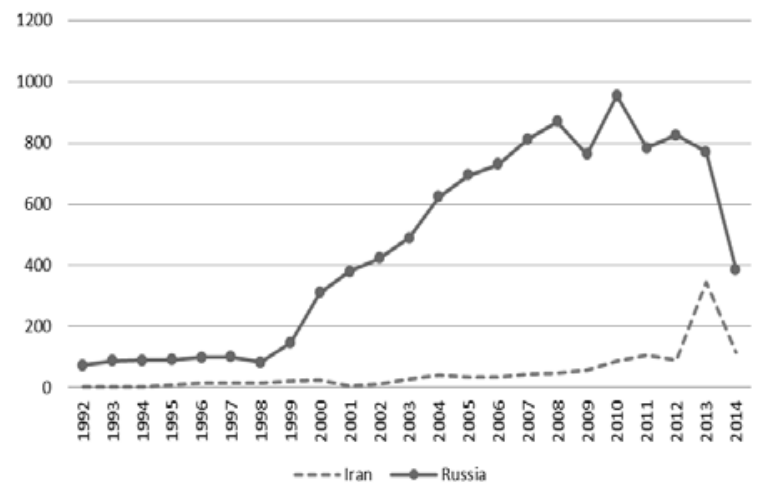

Fig. 1. Market capitalization in Iran and Russia, 1992-2014 (Mln doll.)*

* Source: Compiled by the authors according to the World Bank [20] and Quandl financial and economic data [14].

It can be seen from the above figure that market capitalization in Russia has grown especially between two financial crises (1998-2008). This fact was one of the main factors, generating the high economic growth in Russia. However, after 2011, due to some political conflict, oil price fluctuations and monetary policy of the Central bank of the Russian Federation, the Russian market capitalization or stock market has experienced declines from nearly 954 million dollars in 2010 to about 385 million dollars in 2014. In the case of Iran, it can be noted that the market capitalization in this country has experienced a trend with lower fluctuations. Just in 2011-2012 due to some financial sanctions in regards to its nuclear program S. Mardaneh [12], the indicator has a reduction, but in 2013, the Central bank of Iran decreased sharply interest rate to strengthen the stock market. This policy led to increase of Iran's market capitalization from nearly 90 million dollars in 2012 to 345 million dollars in 2013. However, the sharp oil price reduction in 2014 made it increase to a 
level of 116 million dollars in 2014 (Taghizadeh Hesary et al. [19]).

Besides market capitalization, considering industry growth in these two countries is necessary to explore the development trend of this variable. Here, we use the value added of industry in GDP as a proxy for industry growth. The following figure depicts the contribution of industry in GDP of Iran and Russia over the period 1992-2014. This variable comprises value added in some industries such as mining, manufacturing, construction, electricity, water and gas.

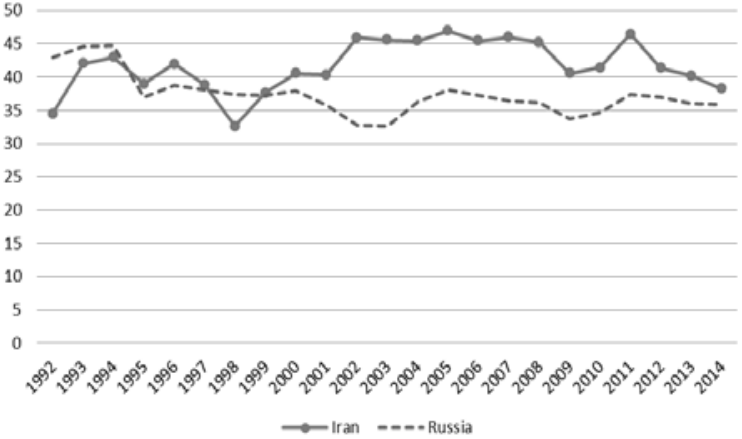

Fig. 2. Value added in industry in Iran and Russia, 1992-2014 (\% of GDP)*

* Source: Compiled by the authors according to the World Bank [20].

It can be seen from the above figure that since the beginning of 2000, Industry value added as a percent of GDP in Iran has moved higher than the value in Russia. It shows the dynamic portion of industry in economy of Iran. However, the growth of the service sector in Russia, particularly after 2000, and the drastic GDP growth are noticeable in interpretation of the reduced movement of this variable in Russia.

Nevertheless, the amount of this variable in Russia is more than it in Iran. The value added of industry in Iran and Russia in constant 2005 U.S. dollars is illustrated in the following fig. 3.

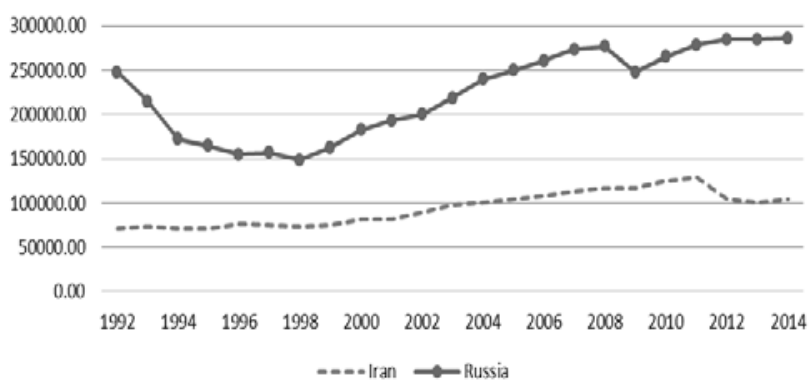

Fig. 3. Value added in industry in Iran and Russia 1992-2014 in constant 2005 prices (Mln doll.)*

* Source: Compiled by the authors according to the World Bank [20].
It is clear that value added of industry in Russia has declined till 1998 from 247559 million dollars in 1992 to 148567 million dollars in 1998. Then, by passing financial crisis and reforming industry capacities, the value added of industry sharply increased till 2009 when it went down from 276319 million dollars in 2008 to nearly 247824 million dollars in 2009. In the case of Iran, this indicator has had a steady increase movement till 2011, while industry value added improved from 71745 million dollars in 1992 to nearly 128172 million dollars in 2011. The imposition of the oil embargo by the EU, the introduction of U.S. sanctions against foreign companies, working in various Iranian industries, and disconnection of Iran from the SWIFT system at the end of 2011, the value added of this sector dropped to 104762 million dollars in 2014.

By considering the above figures, we can conclude that market capitalization and industry growth have a similar trend in Iran and Russia. It is obvious that they have had a same movement during 1992-2014. Means that in Russia, during financial crisis 1998 and 2009, they dropped and by rapid economic growth over the period 2000-2008, they increased. Moreover, in the case of Iran, both of these indicators, have had a flat positive movement from 1992 till the end of 2011. By imposition of various sanctions by the EU and the U.S.A, the economy of Iran was entered to an unusual situation which led to decrease of industry growth and market capitalization. However, the Central bank of Iran with implication of monetary policy improved the market capitalization in 2013.

\section{Estimation Methodology}

To find out the relationship between financial market (with a proxy of market capitalization) and industry growth (with a proxy of value added of industry), we follow basically the Huang-Fang-Miller model [7] which shows the relationship between financial development and industrial growth. Since Iran and Russia are oilbased economy, the oil price plays a crucial role in the industrial growth of them. Hence, we add this variable to our model. Furthermore, we add inflation rate as a monetary variable to our model. Generally,our econometric model can be written as: $\operatorname{LnIND}_{t}=\beta_{1} \operatorname{LnMC}_{t}+\beta_{2} \operatorname{LnInf}_{t}+\beta_{3} \mathrm{LnOil}_{t}+$

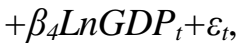
where IND indicates industry growth (value added of industry), $M C$ represents market capitalization, Inf is the inflation rate, Oil depicts oil price and GDP indicates gross domestic products. Meanwhile, $t$ represents time that in our study is from 1992 to 2014.

In order to estimate our econometric model The Vector Autoregressive model is applied. 
Vector Autoregressive model (VAR) is one of the econometric methods which was introduced by Sims in 1980. According to Sims idea, this approach has a favorable character of endogeneity of variables. So in this kind of econometric model, we cannot divide the variables into two groups of endogenous and exogenous (F. Ghaffari and $\mathrm{H}$. Naeemi Pazhoh [6]). Mathematically, vector autoregressive model can be written as:

$$
y_{t}=c+\sum_{i=1}^{p} A_{i} \cdot y_{t-1}+\varepsilon_{t} \text {. }
$$

In the above equation, $y_{t}$ is the vector of variables (industry growth, market capitalization, inflation rate, oil price and GDP), $C$ is a vector of intercepts, $y_{t-1}$ is the lag of the variable $y$. Furthermore, $A_{i}$ indicates a time-invariant matrix.

Before running VAR model, we need to find out the order of integration of the variables by applying unit root tests, i.e. Augmented Dickey-Fuller (ADF) and Phillips-Perron (PP) tests in this study. The main difference between these two various tests is their facing with the heteroskedasticity and any serial correlation in the error terms (Nasre Esfahani and Rasoulinezhad [13]). The test regressions for the ADF and PP tests are as follows:

$$
\text { ADFtest }: \Delta Y_{t}=\beta^{\prime} D_{t}+\pi Y_{t-1}+\sum_{j=1}^{p} \varphi_{j} \Delta Y_{t-j}+\varepsilon_{t} \text {. }
$$

In the $\mathrm{ADF}$ equation, $D_{t}$ indicates the deterministic term vector. The $\varepsilon_{\mathrm{t}}$ represents the error term which is serially uncorrelated and also consider as hemoskedastic.

PPtest : $\Delta Y_{t}=\beta^{\prime} D_{t}+\pi Y_{t-1}+\mu_{t}$.

Where $\mu_{t}$ is I (0) and may be heteroskedastic. The PP stationary test ignores the existence of serial correlation and heteroskedasticity in the error terms.

According to the unit root tests, if the variables are integrated of the same order, we would run the Johansen-Juselius cointegration test (two different likelihood ratio tests, i.e. the trace test and maximum eigenvalue test) to obtain the number of co-integrating vectors (Before running this test, we would imply the Lag Length Selection to detect the lag length using three popular criteria as AIC, BIC and HQ).

If the Johansen-Juselius suggests that variables are not co-integrated, we will perform a VAR model, otherwise we have to develop an error correction model in VECM structure.

\section{Results}

In order to evaluate the stationarity of all series, we performed two unit root tests on all variables at levels and first differences. The tests used are the augmented Dickey-Fuller (ADF) test and Phillips-Perron test. The results are summarized in table 1 and table 2 . We can conclude all the variables become stationary through doing first difference or in other words, all time series are I(1).

\begin{tabular}{|c|c|c|c|c|c|c|c|}
\hline Country & Variable & $\begin{array}{c}\text { ADF Test } \\
\text { Statistic }\end{array}$ & $\begin{array}{c}\text { 1\% Critical } \\
\text { Value }\end{array}$ & $\begin{array}{c}5 \% \\
\text { Critical } \\
\text { Value }\end{array}$ & $\begin{array}{c}10 \% \\
\text { Critical } \\
\text { Value }\end{array}$ & HO & Stationary \\
\hline \multirow[t]{5}{*}{ Russia } & $\begin{array}{c}\text { LIND } \\
\text { D(LIND) }\end{array}$ & $\begin{array}{l}-2.55 \\
-5.87\end{array}$ & $\begin{array}{l}-3.64 \\
-3.65\end{array}$ & $\begin{array}{l}-2.95 \\
-2.95\end{array}$ & $\begin{array}{l}-2.61 \\
-2.61 \\
\end{array}$ & $\begin{array}{l}\text { Accept } \\
\text { Reject }\end{array}$ & $\begin{array}{l}\text { No } \\
\text { Yes }\end{array}$ \\
\hline & $\begin{array}{c}\text { LGDP } \\
\text { D(LGDP) }\end{array}$ & $\begin{array}{r}1.60 \\
-7.20 \\
\end{array}$ & $\begin{array}{l}-3.64 \\
-3.65 \\
\end{array}$ & $\begin{array}{l}-2.95 \\
-2.95 \\
\end{array}$ & $\begin{array}{l}-2.61 \\
-2.61 \\
\end{array}$ & $\begin{array}{l}\text { Accept } \\
\text { Reject }\end{array}$ & $\begin{array}{l}\text { No } \\
\text { Yes }\end{array}$ \\
\hline & $\begin{array}{c}\text { LMC } \\
\text { D(LMC) }\end{array}$ & $\begin{array}{c}1.76 \\
-3.41\end{array}$ & $\begin{array}{l}-3.64 \\
-3.65\end{array}$ & $\begin{array}{l}-2.95 \\
-2.95\end{array}$ & $\begin{array}{l}-2.61 \\
-2.61\end{array}$ & $\begin{array}{l}\text { Accept } \\
\text { Reject }\end{array}$ & $\begin{array}{c}\text { No } \\
\text { Yes at } 5 \%, 10 \%\end{array}$ \\
\hline & $\begin{array}{c}\text { LINF } \\
\text { D(LINF) }\end{array}$ & $\begin{array}{l}-2.38 \\
-4.93\end{array}$ & $\begin{array}{l}-3.64 \\
-3.65\end{array}$ & $\begin{array}{l}-2.95 \\
-2.95\end{array}$ & $\begin{array}{l}-2.61 \\
-2.61\end{array}$ & $\begin{array}{l}\text { Accept } \\
\text { Reject }\end{array}$ & $\begin{array}{l}\text { No } \\
\text { Yes }\end{array}$ \\
\hline & $\begin{array}{c}\text { LOIL } \\
\text { D(LOIL) }\end{array}$ & $\begin{array}{c}7.26 \mathrm{E}-05 \\
-5.16 \\
\end{array}$ & $\begin{array}{l}-3.64 \\
-3.65 \\
\end{array}$ & $\begin{array}{l}-2.95 \\
-2.95 \\
\end{array}$ & $\begin{array}{l}-2.61 \\
-2.61 \\
\end{array}$ & $\begin{array}{c}\text { Accept } \\
\text { Reject }\end{array}$ & $\begin{array}{l}\text { No } \\
\text { Yes }\end{array}$ \\
\hline \multirow[t]{5}{*}{ Iran } & $\begin{array}{c}\text { LIND } \\
\text { D(LIND) }\end{array}$ & $\begin{array}{l}-2.82 \\
-6.32\end{array}$ & $\begin{array}{l}-3.64 \\
-3.65\end{array}$ & $\begin{array}{l}-2.95 \\
-2.95\end{array}$ & $\begin{array}{l}-2.61 \\
-2.61\end{array}$ & $\begin{array}{l}\text { Accept } \\
\text { Reject }\end{array}$ & $\begin{array}{l}\text { No } \\
\text { Yes }\end{array}$ \\
\hline & $\begin{array}{c}\text { LGDP } \\
\text { D(LGDP) }\end{array}$ & $\begin{array}{l}-1.47 \\
-4.80 \\
\end{array}$ & $\begin{array}{l}-3.64 \\
-3.65 \\
\end{array}$ & $\begin{array}{l}-2.95 \\
-2.95 \\
\end{array}$ & $\begin{array}{l}-2.61 \\
-2.61 \\
\end{array}$ & $\begin{array}{l}\text { Accept } \\
\text { Reject }\end{array}$ & $\begin{array}{l}\text { No } \\
\text { Yes }\end{array}$ \\
\hline & $\begin{array}{c}\text { LMC } \\
\text { D(LMC) }\end{array}$ & $\begin{array}{l}-1.12 \\
-4.06 \\
\end{array}$ & $\begin{array}{l}-3.64 \\
-3.65 \\
\end{array}$ & $\begin{array}{l}-2.95 \\
-2.95 \\
\end{array}$ & $\begin{array}{l}-2.61 \\
-2.61 \\
\end{array}$ & $\begin{array}{l}\text { Accept } \\
\text { Reject }\end{array}$ & $\begin{array}{l}\text { No } \\
\text { Yes }\end{array}$ \\
\hline & $\begin{array}{c}\text { LINF } \\
\text { D(LINF) }\end{array}$ & $\begin{array}{l}-0.22 \\
-5.58\end{array}$ & $\begin{array}{l}-3.64 \\
-3.65\end{array}$ & $\begin{array}{l}-2.95 \\
-2.95\end{array}$ & $\begin{array}{l}-2.61 \\
-2.61\end{array}$ & $\begin{array}{l}\text { Accept } \\
\text { Reject }\end{array}$ & $\begin{array}{l}\text { No } \\
\text { Yes }\end{array}$ \\
\hline & $\begin{array}{c}\text { LOIL } \\
\text { D(LOIL) }\end{array}$ & $\begin{array}{l}-0.61 \\
-8.12\end{array}$ & $\begin{array}{l}-3.64 \\
-3.65\end{array}$ & $\begin{array}{l}-2.95 \\
-2.95\end{array}$ & $\begin{array}{l}-2.61 \\
-2.61\end{array}$ & $\begin{array}{l}\text { Accept } \\
\text { Reject }\end{array}$ & $\begin{array}{l}\text { No } \\
\text { Yes }\end{array}$ \\
\hline
\end{tabular}

Augmented Dickey-Fuller unit root test results

Note: “ADF” test is augmented Dickey-Fuller test, "D” refers to first differences. 
Table 2

PP unit root test results

\begin{tabular}{|c|c|c|c|c|c|c|c|}
\hline Country & Variable & $\begin{array}{l}\text { PP Test } \\
\text { Statistic }\end{array}$ & $\begin{array}{c}\text { 1\% Critical } \\
\text { Value }\end{array}$ & $\begin{array}{c}5 \% \\
\text { Critical } \\
\text { Value }\end{array}$ & $\begin{array}{c}10 \% \\
\text { Critical } \\
\text { Value }\end{array}$ & HO & Stationary \\
\hline \multirow[t]{5}{*}{ Russia } & $\begin{array}{c}\text { LIND } \\
\text { D(LIND) }\end{array}$ & $\begin{array}{l}-2.47 \\
-6.16\end{array}$ & $\begin{array}{l}-3.63 \\
-3.65\end{array}$ & $\begin{array}{l}-2.94 \\
-2.95\end{array}$ & $\begin{array}{l}-2.62 \\
-2.61\end{array}$ & $\begin{array}{l}\text { Accept } \\
\text { Reject }\end{array}$ & $\begin{array}{l}\text { No } \\
\text { Yes }\end{array}$ \\
\hline & $\begin{array}{c}\text { LGDP } \\
\text { D(LGDP) }\end{array}$ & $\begin{array}{c}1.54 \\
-6.83\end{array}$ & $\begin{array}{l}-3.63 \\
-3.65\end{array}$ & $\begin{array}{l}-2.94 \\
-2.95\end{array}$ & $\begin{array}{l}-2.62 \\
-2.61\end{array}$ & $\begin{array}{l}\text { Accept } \\
\text { Reject }\end{array}$ & $\begin{array}{l}\text { No } \\
\text { Yes }\end{array}$ \\
\hline & $\begin{array}{c}\text { LMC } \\
\text { D(LMC) }\end{array}$ & $\begin{array}{c}1.65 \\
-4.40\end{array}$ & $\begin{array}{l}-3.63 \\
-3.65\end{array}$ & $\begin{array}{l}-2.94 \\
-2.95\end{array}$ & $\begin{array}{l}-2.62 \\
-2.61\end{array}$ & $\begin{array}{l}\text { Accept } \\
\text { Reject }\end{array}$ & $\begin{array}{l}\text { No } \\
\text { Yes }\end{array}$ \\
\hline & $\begin{array}{c}\text { LINF } \\
\text { D(LINF) }\end{array}$ & $\begin{array}{l}-2.29 \\
-4.76\end{array}$ & $\begin{array}{l}-3.63 \\
-3.65\end{array}$ & $\begin{array}{l}-2.94 \\
-2.95\end{array}$ & $\begin{array}{l}-2.62 \\
-2.61\end{array}$ & $\begin{array}{l}\text { Accept } \\
\text { Reject }\end{array}$ & $\begin{array}{l}\text { No } \\
\text { Yes }\end{array}$ \\
\hline & $\begin{array}{c}\text { LOIL } \\
\text { D(LOIL) }\end{array}$ & $\begin{array}{c}1.26 \\
-5.16\end{array}$ & $\begin{array}{l}-3.63 \\
-3.65\end{array}$ & $\begin{array}{l}-2.94 \\
-2.95\end{array}$ & $\begin{array}{l}-2.62 \\
-2.61\end{array}$ & $\begin{array}{l}\text { Accept } \\
\text { Reject }\end{array}$ & $\begin{array}{l}\text { No } \\
\text { Yes }\end{array}$ \\
\hline \multirow[t]{5}{*}{ Iran } & $\begin{array}{c}\text { LIND } \\
\text { D(LIND) }\end{array}$ & $\begin{array}{l}-2.81 \\
-6.33\end{array}$ & $\begin{array}{l}-3.63 \\
-3.65\end{array}$ & $\begin{array}{l}-2.94 \\
-2.95\end{array}$ & $\begin{array}{l}-2.62 \\
-2.61\end{array}$ & $\begin{array}{c}\text { Accept } \\
\text { Reject }\end{array}$ & $\begin{array}{l}\text { No } \\
\text { Yes }\end{array}$ \\
\hline & $\begin{array}{c}\text { LGDP } \\
\text { D(LGDP) }\end{array}$ & $\begin{array}{l}-1.49 \\
-4.79 \\
\end{array}$ & $\begin{array}{l}-3.63 \\
-3.65 \\
\end{array}$ & $\begin{array}{l}-2.94 \\
-2.95 \\
\end{array}$ & $\begin{array}{l}-2.62 \\
-2.61 \\
\end{array}$ & $\begin{array}{c}\text { Accept } \\
\text { Reject }\end{array}$ & $\begin{array}{l}\text { No } \\
\text { Yes }\end{array}$ \\
\hline & $\begin{array}{c}\text { LMC } \\
\text { D(LMC) }\end{array}$ & $\begin{array}{l}-1.20 \\
-4.10\end{array}$ & $\begin{array}{l}-3.63 \\
-3.65\end{array}$ & $\begin{array}{l}-2.94 \\
-2.95\end{array}$ & $\begin{array}{l}-2.62 \\
-2.61\end{array}$ & $\begin{array}{l}\text { Accept } \\
\text { Reject }\end{array}$ & $\begin{array}{l}\text { No } \\
\text { Yes }\end{array}$ \\
\hline & $\begin{array}{c}\text { LINF } \\
\text { D(LINF) }\end{array}$ & $\begin{array}{l}-1.01 \\
-5.53\end{array}$ & $\begin{array}{l}-3.63 \\
-3.65\end{array}$ & $\begin{array}{l}-2.94 \\
-2.95\end{array}$ & $\begin{array}{l}-2.62 \\
-2.61\end{array}$ & $\begin{array}{l}\text { Accept } \\
\text { Reject }\end{array}$ & $\begin{array}{l}\text { No } \\
\text { Yes }\end{array}$ \\
\hline & $\begin{array}{c}\text { LOIL } \\
\text { D(LOIL) }\end{array}$ & $\begin{array}{l}-0.77 \\
-7.83\end{array}$ & $\begin{array}{l}-3.63 \\
-3.65\end{array}$ & $\begin{array}{l}-2.94 \\
-2.95\end{array}$ & $\begin{array}{l}-2.62 \\
-2.61\end{array}$ & $\begin{array}{l}\text { Accept } \\
\text { Reject }\end{array}$ & $\begin{array}{l}\text { No } \\
\text { Yes }\end{array}$ \\
\hline
\end{tabular}

Note: PP test is Phillips-Perron test, "D" refers to first differences.

As we have found out from the unit root tests, all our series are I(1), hence, it is possible now to check the presence of a long run cointegrating relation among the endogenous variables. But, before proceeding the cointegration test, we should find the convenient and optimal lag length. In this present research, we choose optimal lag numbers using the Akaike Information Criteria (AIC), Hannan-Quinn Criterion (HQC) and Schwarz information criterion (table 3), which suggest one lag. This lag number is used for the cointegration test and also the remaining research analysis.

Selection of Lag Length

Table 3

\begin{tabular}{|c|c|c|c|c|}
\hline Country & Lag & Akaike Information Criterion & Schwarz Information Criterion & Hannan-Quinn Criterion \\
\hline \multirow{4}{*}{ Russia } & 0 & -4.84 & -4.61 & -4.76 \\
\cline { 2 - 5 } & 1 & -11.9 & $\mathbf{- 1 0 . 5 8}$ & $-\mathbf{1 1 . 5 *}$ \\
\cline { 2 - 5 } & 2 & -12.9 & -9.64 & -11.36 \\
\cline { 2 - 5 } & 3 & $-12.59^{*}$ & -8.89 & -11.38 \\
\hline \multirow{3}{*}{ Iran } & 0 & -2.31 & -2.54 & -2.39 \\
\cline { 2 - 5 } & 1 & $-\mathbf{6 . 2 0}$ & $\mathbf{- 4 . 8 0 ^ { * }}$ & $-\mathbf{5 . 7 5 *}$ \\
\cline { 2 - 5 } & 2 & -5.56 & -3.02 & -4.73 \\
\cline { 2 - 5 } & 3 & -5.79 & -2.09 & -4.58 \\
\hline
\end{tabular}

Note: * shows the optimized lag by the criteria.

The following table reports Johansen cointegration test results. It can be seen that both the Trace and Maximum Eigenvalue test do not suggest the existence of the cointegration relationship among research variables at the 0.05 level.

Table 4

Johansen and Juselius Cointegration Test results

\begin{tabular}{|c|c|c|c|c|}
\hline \multirow{3}{*}{ Russia } & \multicolumn{4}{|c|}{ Trace test } \\
\cline { 2 - 5 } & No. of cointegrations & Eigenvalue & Trace statistic & Critical value 0.05 \\
\cline { 2 - 5 } & None & 0.49 & 59.37 & 60.06 \\
\cline { 2 - 5 } & At most 1 & 0.40 & 37.24 & 40.17 \\
\cline { 2 - 5 } & At most 2 & 0.32 & 20.65 & 24.27 \\
\cline { 2 - 5 } & At most 3 & 0.18 & 8.29 & 12.32 \\
\cline { 2 - 5 } & At most 4 & 0.04 & 1.55 & 4.12 \\
\hline
\end{tabular}




\begin{tabular}{|c|c|c|c|c|}
\hline & \multicolumn{4}{|c|}{ The end of table 4} \\
\hline \multirow[t]{7}{*}{ Russia } & \multicolumn{4}{|c|}{ Maximum Eigenvalue test } \\
\hline & No. of cointegrations & Eigenvalue & Max-Eigen statistic & Critical value 0.05 \\
\hline & None & 0.49 & 22.12 & 30.43 \\
\hline & At most 1 & 0.40 & 16.58 & 24.15 \\
\hline & At most 2 & 0.32 & 12.36 & 17.79 \\
\hline & At most 3 & 0.18 & 6.73 & 11.22 \\
\hline & At most 4 & 0.04 & 1.55 & 4.12 \\
\hline \multirow{14}{*}{ Iran } & \multicolumn{4}{|c|}{ Trace test } \\
\hline & No. of cointegrations & Eigenvalue & Trace statistic & Critical value 0.05 \\
\hline & None & 0.62 & 68.92 & 69.81 \\
\hline & At most 1 & 0.44 & 37.40 & 47.85 \\
\hline & At most 2 & 0.31 & 18.77 & 29.79 \\
\hline & At most 3 & 0.18 & 6.72 & 15.49 \\
\hline & At most 4 & 0.00 & 0.04 & 3.84 \\
\hline & \multicolumn{4}{|c|}{ Maximum Eigenvalue test } \\
\hline & No. of cointegrations & Eigenvalue & Max-Eigen statistic & Critical value 0.05 \\
\hline & None & 0.62 & 31.52 & 33.87 \\
\hline & At most 1 & 0.44 & 18.63 & 27.58 \\
\hline & At most 2 & 0.31 & 12.05 & 21.13 \\
\hline & At most 3 & 0.18 & 6.67 & 14.26 \\
\hline & At most 4 & 0.00 & 0.04 & 3.84 \\
\hline
\end{tabular}

Since the cointegration test does not show any cointegration between variables, hence we can run the VAR model. The results of the Vector Autoregressive (VAR) model for Russia are reported in the following equation (equation 5 ). $\operatorname{LINDRU}=0.24 \cdot \operatorname{LINDRU}(-1)+0.04 \cdot \operatorname{LGDPRU}(-1)+$

$$
+0.07 \cdot \operatorname{LMCRU}(-1)-0.008 \cdot \operatorname{LINFRU}(-1)+
$$

$+0.04 \cdot \operatorname{LOIL}(-1)+16.277$

It is obvious that a $1 \%$ increase in the industry growth in Russia can increase the future industry growth by $0.24 \%$. Furthermore, oil price and GDP have positive relationship with industry growth in Russia. A 1\% increase in GDP and oil prices may lead to $0.04 \%$ increase in industry growth. Inflation has a negative impact on industry growth of Russia. Means that a 1\% increase in inflation rate in Russia can decrease the industry growth of this country by $-0.008 \%$. Finally, the result shows that market capitalization has a positive relationship with industry growth in Russia and $1 \%$ increase in this variable improves the industry growth by $0.07 \%$, which is higher than the effects of GDP, oil prices and inflation rate.

In the case of Iran (equation 6), the results depict the positive impact of current industry growth on the future industry growth. In other words, a $1 \%$ increase in industry growth in Iran will lead to $0.92 \%$ increase in the future industry growth. Also, market capitalization has a positive connection with industry growth in Iran by a positive coefficient of 0.02 . Moreover, a $1 \%$ increase in oil prices can increase the industry growth by $0.01 \%$. The findings prove the negative relationship of inflation rate and GDP with industry growth. A $1 \%$ increase in GDP and inflation rate may lead to reduction of industry growth by $0.06 \%$ and $0.04 \%$, respectively. $\operatorname{LINDIR}=0.92 \cdot \operatorname{LINDIR}(-1)-0.06 \cdot \operatorname{LGDPIR}(-1)+$

$+0.02 \cdot \operatorname{LMCIR}(-1)+0.01 \mathrm{LOIL}(-1)-$

$-0.04 \cdot \operatorname{LINFIR}(-1)+3.07$

In regards to the negative relationship between GDP and industry growth in Iran, one of the main reasons is the existence of the Dutch Disease, which means the economic growth in Iran is generated by natural resource export revenues and due to the lack of management, these revenues in Iran always lead to national currency appreciation which makes the local industries less competitive in the world market. This circumstance causes problems for the local industries in Iran. Many previous studies proved the existence of Dutch disease in the economy of Iran such as S. Mardaneh [12], Manzoor et al. [11] and Salehi Esfahani et al. [16].

\section{Conclusions}

This research has empirically attempted to investigate the dynamic nexus between market capitalization and industry growth for two oil exporting countries, i.e. Russia and Iran, for the period 1992-2014 by using the VAR model. It should be noted that in this study for the first time, the relationship between market capitalization and industry growth in Iran and Russia has been considered and this fact proves the novelty of this research.

According to the results, it has been concluded that market capitalization has a positive relationship with industry growth in Iran and Russia. But in Russia, it has a higher positive relationship between them. Means than a $1 \%$ 
increase in market capitalization in Russia will lead to $0.07 \%$ increase in industry growth, while a $1 \%$ increase in Iran's market capitalization may lead to only $0.02 \%$ increase in industry growth.

Furthermore, the results depicted the negative relationship between inflation rate and industry growth. Means that any increase in inflation rate can increase the production cost or lower the purchasing power of households that totally can impact negatively on industry growth. Moreover, based on the fact that these two countries have oil-based economy, we found the positive relationship between oil prices and industrial growth. In fact, petroleum industry in these two countries plays the major role in their economy among other industries. So any increase in oil prices can lead to a higher investment in these industries or lower the investment risk in these countries which finally cause the petroleum industry growth.

In the case of industry growth-GDP nexus, we did not find a similar evidence, as there is a positive relationship between these two variables in Russia, while GDP has a negative connection with industry growth in Iran. As we mentioned before, the basic reason is the existence of the Dutch disease in the economy of Iran. Our this finding is in line with some previous studies such as S. Mardaneh [12] and Salehi Esfahani et al. [16].

\section{References}

1. Bagehot W. Lombard Street: A description of the money market (London, H.S. King). Reprinted in the Col, Homewood, Illinois, 1873. $231 \mathrm{p}$.

2. Beck T., Levine R. Industry growth and capital allocation: does having a market or bank-based system matter? Journal of financial economics, 2002, vol. 64, no. 2, pp. 147-180.

3. Bencivenga V.R., Smith B.D., Starr R.M. Transaction costs, technological choice, and endogenous growth. Journal of Economic Theory, 1995, vol. 67, pp. 53-177.

4. Bhide A. The hidden costs of stock market liquidity. Journal of Financial Economics, 1993, vol. 34, pp. 31-51.

5. Dicle F., Beyhan A., Yao L.J. Market Efficiency and International Diversification: Evidence from India. International Review of Economics \& Finance, 2010, no. 19(2), pp. 313-339.

6. Ghaffari F., Naeemi Pazhoh H. Investigation of effects of inner and outer shocks on inflation of Iran. Quarterly Journal of Economic Polices, 2012, vol. 20, no. 62, pp. 117-142.
7. Huang H.C., Fang W., Miller S.M. Does financial development volatility affect industrial growth volatility? International Review of Economics and Finance, 2014, vol. 29, pp. 307-320.

8. Kim D.H., Lin S.C., Chen T.C. Financial structure, firm size and industry growth. International Review of Economics \& Finance, 2016, vol. 41, pp. 23-39.

9. Levine R. Stock markets, growth and tax policy. Journal of Finance, 1991, vol. 46, pp. 1445-1465.

10. Levine R., Zervos S. Stock markets and economic growth. American Economic Review, 1998, vol. 88, pp. 537-558.

11. Manzoor D., Haqiqi I., Aghababaei M.E. Modeling Dutch Disease in the economy of Iran: A computable General equilibrium approach. Quarterly Energy Economics Review, 2012, vol. 8, no. 31, pp. 59-84.

12. Mardaneh S. Inflation dynamics in a Dutch Disease economy. Working paper in University of Leicester, 2012, no. 12/25, pp. 1-31. Available at: http://www.le.ac.uk/ec/research/ReP Ec/lec/leecon/dp12-25.pdf (accessed 22.01.2016).

13. Nasre Esfahani M., Rasoulinezhad E. Revisiting the relationships between non-renewable energy consumption, $\mathrm{CO} 2$ emissions and economic growth in Iran. MPRA working paper, 2016, no. 71124, pp. 1-27. Available at: https://mpra.ub .uni-muenchen.de/71124/ (accessed 22.05.2016).

14. Quandl Financial and Economic data. Available at: https://www.quandl.com/ (accessed 03.02.2016).

15. Rajan R.G., Zingales L. Financial dependence and growth. American Economic Review, 1998, vol. 88, pp. 559-586.

16. Salehi Esfahani H., Mohaddes K., Pesaran M.H. Oil exports and the Iranian economy. CESifo Working paper, 2009, no. 2843. pp. 1-43. Available at: https://papers.ssrn.com/sol3/paper s.cfm?abstract_id=1501973 (accessed 12.02.2016).

17. Shleifer A., Vishny R.W. Large shareholders and corporate control. Journal of Political Economy, 1986, vol. 96, pp. 461-488.

18. Schumpeter J. A theory of economic development. Cambridge, Massachusetts, Harvard University Press, 1911. 255 p.

19. Taghizadeh Hesary F., Rasoulinezhad E., Kobayashi Y. Oil Price Fluctuations and Oil Consuming Sectors: An Empirical Analysis of Japan. ADBI working paper, 2015, no. 539, pp. 1-17. Available at: https://www.econstor.eu/bi tstream/10419/115356/1/833008366.pdf (accessed 12.02.2016). 
20. The World Bank data base. Available at: http://data.worldbank.org/indicator/CM.MKT. LCAP.GD.ZS (accessed 03.02.2016).
The date of the manuscript receipt: 04.06.2016.

\section{ВЛИЯНИЕ ФИНАНСОВОГО РЫНКА НА РОСТ ПРОМЫШЛЕННОСТИ: НА ПРИМЕРЕ РОССИИ И ИРАНА}

И.Г. Сергеева, докт. экон. наук, профессор, зав. кафедрой финансового менеджмента и аудита Электронный адрес: Igsergeeva@gmail.com

Санкт-Петербургский национальный исследовательский университет информационных технологий, механики и оптики, 191002, Россия, Санкт-Петербург, ул. Ломоносова, 9

T. Тайебехсадат, аспирант

Электронный адрес: Tstaba64@gmail.com

Санкт-Петербургский национальный исследовательский университет информационных технологий, механики и оптики, 191002, Россия, Санкт-Петербург, ул. Ломоносова, 9

Наличие взаимосвязи между финансовыми рынками и ростом промышленности подтверждается результатами многих исследований. В данной статье ставится задача оценки влияния рыночной капитализации финансового рынка на рост промышленности на примере России и Ирана. Гипотезу исследования составляет предположение о том, что в развивающихся странах, таких как Россия и Иран, финансовые рынки могут служить мощным двигателем роста промышленного производства. Соответственно, исследование взаимосвязи между рыночной капитализацией финансового рынка и ростом промышленности в России и Иране представляется актуальной и практически значимой задачей. Решение данной задачи реализовано посредством построения эконометрической модели векторной авторегрессии анализа данных за период с 1992 по 2014 гг. Результаты исследования подтверждают наличие положительной взаимосвязи между рыночной капитализацией финансового рынка и ростом промышленности в обеих странах. Так, согласно проведенным расчетам увеличение рыночной капитализации в Иране и России на $1 \%$ увеличивает рост промышленности на $0,07 \%$ и $0,02 \%$ соответственно. Таким образом, можно сделать вывод о том, что рыночная капитализация финансового рынка оказывает существенное влияние на рост промышленности в исследуемых странах. Тем не менее России и Ирану необходимо повысить эффективность своих финансовых рынков, чтобы усилить их положительное влияние на рост промышленности. Результаты исследования позволяют сделать вывод, что финансовый рынок в странах - экспортерах нефти (в нашем случае - России и Иране) может стать ключом к достижению положительного и стабильного экономического роста. Таким образом, страны - экспортеры нефти должны прилагать усилия к тому, чтобы проводить надлежащую финансовую политику с целью повышения эффективность финансового рынка.

Ключевые слова: рыночная капитализация, финансовый рынок, рост промылиленности, эффективность финансового рынка, анализ временных рядов, экономическое моделирование, модель векторной авторегрессии, тест на единичные корни, выбор задержки, коинтеграционный анализ.

Просьба ссылаться на эту статью в русскоязычных источниках следующим образом:

Сергеева И.Г., Тайебехсадат Т. Влияние финансового рынка на рост промышленности: на примере России и Ирана // Вестник Пермского университета. Сер. «Экономика» = Perm University Herald. Economy. 2016. № 4(31). C. 66-73. doi: 10.17072/1994-9960-2016-4-66-73

Please cite this article in English as:

Sergeeva I.G., Tayebehsadat T. The impact of financial market on industry growth: an evidence from Russia and Iran // Vestnik Permskogo universiteta. Seria Ekonomika = Perm University Herald. Economy. 2016. № 4(31). P. 66-73. doi: 10.17072/1994-9960-2016-4-66-73 